\title{
LEAD POISONING IN THE GLOBALLY THREATENED MARBLED TEAL AND WHITE-HEADED DUCK IN SPAIN
}

\author{
Rafael Mateo,*† Andy J. Green, $\neq$ Clinton W. Jeske,§ Vicente Urios,W and Cati Gerique\# \\ $\dagger$ Laboratory of Toxicology, Faculty of Veterinary, Autonomous University of Barcelona, Bellaterra 08193, Spain \\ ‡Department of Applied Biology, Estación Biológica de Doñana, CSIC, Avenida de María Luisa s/n, Sevilla 41013, Spain \\ §National Wetlands Research Center, 700 Cajundome Boulevard, Lafayette, Louisiana 70506, USA \\ WDepartment of Environmental Science and Natural Resources, University of Alicante, Alicante 03080, Spain \\ \#Center for Nature Protection and Study, Departament de Medi Ambient, Generalitat Valenciana, Avenida de los Pinares 106, \\ El Saler 46012, Spain
}

\begin{abstract}
Marbled teal (Marmaronetta angustirostris) and white-headed duck (Oxyura leucocephala) are the two European ducks threatened with global extinction. We investigated lead $(\mathrm{Pb})$ poisoning in stifftails (Oxyura spp., $n=83)$ and marbled teal $(n=$ 80) shot or found dead or moribund in Spanish wetlands via gizzard examination and liver, bone, and blood $\mathrm{Pb}$ analysis. Ingested $\mathrm{Pb}$ shot was present in $32 \%$ of shot stifftails and 70 and $43 \%$ of dead or moribund stifftails and marbled teal, respectively. Leadshot ingestion was more frequent in Valencia (eastern Spain), where Pb-shot densities were higher and grit scarcer. Selection of larger grit similar in size to $\mathrm{Pb}$ shot may explain the higher rate of Pb-shot ingestion observed in stifftails. Ingested shot was found more frequently in juvenile stifftails than in adults. Lead bone concentrations were higher in ducklings $<9 \mathrm{~d}$ old than in fully grown teal and were also higher in adult than in juvenile teal. Our results show the need for a ban of $\mathrm{Pb}$ shot for waterfowl hunting in Spain and the cleanup of spent shot at major wetlands.
\end{abstract}

Keywords-Heavy metal contamination Lead shot Waterfowl Grit Wetlands

\section{INTRODUCTION}

Lead poisoning as a result of ingestion of spent $\mathrm{Pb}$ shot in wetlands has been a major cause of waterfowl mortality [1]. Lead-shot densities in wetlands along the Mediterranean coast of Europe, where all hunters still use $\mathrm{Pb}$ shot, are among the highest recorded anywhere in the world [2]. The prevalence of Pb-shot ingestion in the widespread mallard (Anas platyrhynchos) ranges in Mediterranean wetlands from 20 to $45 \%$ [2-6]. The prevalence registered for mallard or the related black duck (Anas rubripes) in Britain or North America, where $\mathrm{Pb}$ shot has been banned for over a decade, was $<10 \%$ [79]. However, in some southern states of the United States, the exposure in mallard and the related mottled duck (Anas fulvigula) equaled the values observed in Mediterranean Europe $[8,10]$.

Two of the species most affected by $\mathrm{Pb}$ poisoning in Mediterranean wetlands are the northern pintail (Anas acuta) and the common pochard (Aythya ferina), which have prevalences of $\mathrm{Pb}$-shot ingestion of 50 to $70 \%[2-4,11]$ and have undergone population declines in Europe over the past 25 years [12]. These are still relatively widespread and abundant species of waterfowl. However, it has previously been suggested that $\mathrm{Pb}$ poisoning may be a significant cause of mortality for the two duck species present in Europe that meet the World Conservation Union criteria for globally threatened status [13], the marbled teal (Marmaronetta angustirostris) and the whiteheaded duck (Oxyura leucocephala) [14].

Here we present the first study of $\mathrm{Pb}$ poisoning in the marbled teal and white-headed duck. We focus on Spain, the most important European range country for both species, which are

* To whom correspondence may be addressed (rafael.mateo@uab.es). resident there. The marbled teal has undergone a long-term decline in Spain [15] and elsewhere in its range, having a remaining world population of 15,000 to 25,000 individuals [13]. Since 1990, total numbers in Spain have fluctuated between approximately 50 and 700 ([16], A.J. Green, unpublished data). The marbled teal is a dabbling duck in ecological (but not taxonomic) terms [16].

The white-headed duck is the only stifftail (tribe Oxyurini, a group of diving ducks) native to the Palearctic. It has a fragmented distribution and a declining world population of 10,000 to 20,000 birds [13]. In Spain, numbers have recovered from 22 birds in 1977 to 1,453 in 1999 in response to conservation measures, especially protection from hunting [17]. The Spanish population of the white-headed duck is affected by the spread of the North American ruddy duck, Oxyura jamaicensis jamaicensis, introduced to northern Europe [14]. Ruddy ducks produce fertile hybrids with the white-headed ducks; both ruddy ducks and hybrids are shot by governmental conservation organizations to counter genetic integration [14]. The white-headed duck, ruddy duck, and their hybrids flock together and have very similar foraging ecology [18] and grit selection (this study) and can be expected to respond to $\mathrm{Pb}$ exposure in a similar way. We therefore include the ruddy duck and their hybrids shot or found dead in Spain in this study as a useful surrogate for studying $\mathrm{Pb}$ exposure in the globally threatened white-headed duck.

We assess the frequency of Pb-shot ingestion in both stifftails and teal in different parts of Spain and the proportion of the populations affected by toxic levels of $\mathrm{Pb}$ in tissues. We assess the differences between age classes and sexes in the prevalence of $\mathrm{Pb}$ exposure by shot ingestion. We compare the composition of grit ingested by each taxon in different regions 


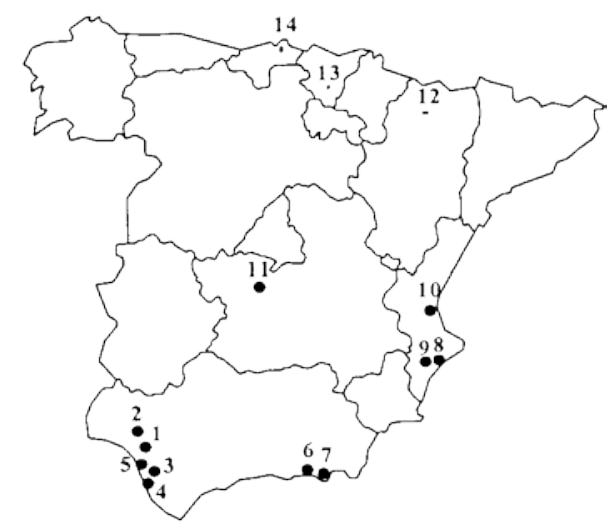

Fig. 1. Location of autonomous communities and wetlands where stifftails and marbled teal were collected in Spain. Wetlands 1 through 11, marked with circles, are within the range of the white-headed duck and marbled teal. Numbers of birds ( $\mathrm{L}=$ white-headed duck, $\mathrm{J}=$ ruddy duck, $\mathrm{H}=$ hybrid, $\mathrm{M}=$ fully grown marbled teal, $\mathrm{m}=$ teal chick) collected at each wetland are as follows. Andalucía: $1=$ Veta la Palma, Doñana, Sevilla, H (6), J (1), M (6); 2 = Lucio del Cangrejo Grande, Doñana, Sevilla, J (1); 3 = Laguna de Medina, Cádiz, J (1); 4 = Lagunas de Puerto Real, Cádiz, J (1); 5 = Laguna de Tarelo, Doñana, Cádiz, H (4), J (2); 6 = Albufera de Adra, Almería, H (2), $\mathrm{J}$ (1); 7 = Punta Entinas-Sabinar and nearby, Almería, J (3), H (2). Valencia: 8 = Santa Pola, Alicante M (4); $9=$ El Hondo, Alicante, J (8), H (12), L (28), M (48), m (20); 10 = Albufera de Valencia, L (1), M (1), m (1). Castilla-la Mancha: 11 = Dehesa de Monreal, Toledo, H (1). Aragón: 12 = Laguna de Sariñ era, Huesca, J (1). País Vasco: 13, Ullibarri-Gamboa, Álava, J (7). Cantabria: 14, Marisma de Santoña, J (1).

and consider how this relates to the rates of Pb-shot ingestion. We also investigate the levels of $\mathrm{Pb}$ found in newly hatched ducklings (not subjected directly to ingested $\mathrm{Pb}$ shot), an issue not previously studied in any waterfowl species.

\section{MATERIALS AND METHODS}

\section{Collection of specimens}

We studied a total of 83 stifftails (29 white-headed ducks, 26 ruddy ducks, and 28 hybrids) collected from 14 Spanish wetlands (Fig. 1) at different times of the year [18]. Most ruddy ducks and hybrids were shot during a control program organized by the Spanish regional and national administrations. These birds were tracked down and hunted individually by marksmen, and we do not anticipate a bias toward shooting birds more exposed to $\mathrm{Pb}$. The white-headed ducks were either found dead or dying (usually during epizootic outbreaks of salmonellosis, botulism, or other diseases) or shot (either incidentally during the ruddy duck control program or shot illegally and then confiscated).

We studied a total of 80 marbled teal, including 59 fully grown birds and 21 ducklings (19 of the youngest age class Ia of 1-8 d old, 2 of class II of 18-41 d old [19]). All except seven fully grown birds and one duckling came from El Hondo and Santa Pola along the Mediterranean coast in the autonomous community of Valencia in eastern Spain (Fig. 1). All but three fully grown birds were found dead or dying, and 45 of them were collected during a die-off at El Hondo from September to November 1997 that was apparently caused by organophosphate poisoning and botulism (C. Gerique, unpublished data). Most ducklings died shortly after being rescued from a concrete-lined drainage canal in El Hondo, in which hundreds of ducklings were trapped each year [20] until ramps were installed in 1999.
In order to study regional differences in the prevalence of $\mathrm{Pb}$ exposure by shot ingestion, we compared those birds from the autonomous community of Valencia with those coming from other parts of Spain. Compared with other areas, Valencian wetlands have particularly high densities of $\mathrm{Pb}$ shot [6], and most of our birds came from El Hondo, where densities of up to $163 \mathrm{shot} / \mathrm{m}^{2}$ are recorded [21]. El Hondo is the most important European wetland for both marbled teal and whiteheaded ducks [15].

Treatment of birds varied considerably in this heterogeneous sample, involving many organizations and people. Blood samples $(0.2-0.5 \mathrm{ml})$ were taken from eight sick whiteheaded ducks upon arrival at the Center for Nature Protection and Study in Valencia. Blood samples were collected in metalfree tubes with sodium heparin and frozen to $-20^{\circ} \mathrm{C}$ before analysis. Most dead birds were frozen shortly after collection and were sent to the Doñana National Park or Doñana Biological Station for necropsy. Fully grown birds were sexed and aged (adults or juveniles) based on plumage characteristics, gonad inspection, and presence or absence of the bursa of Fabricius [19,22]. Samples of liver and bone (humerus and/or femur) were removed and stored in metal-free plastic vials.

\section{Analysis of $\mathrm{Pb}$-shot presence and $\mathrm{Pb}$ concentrations}

Gizzards were examined externally for the presence of shot entry holes to establish whether shot found within had been shot in or ingested. Each gizzard was cut with scissors and its contents washed with water and then dried. Food items were removed by flotation. The precipitate was dried and placed in plastic Petri dishes. After $\mathrm{Pb}$ shot were removed and weighed, grit was sieved (sieve sizes 4, 3, 2, 1.5, 1, and $0.5 \mathrm{~mm}$ ) and each size class of particles was weighed [5]. Lead shot was excluded from analyses of grit composition.

Livers were analyzed at the Autonomous University of Barcelona (Barcelona, Spain), bones at the National Wetlands Research Center, and blood samples at the Sagunto 99 Laboratory of Veterinary Analysis (Valencia, Spain). Livers were homogenized and a portion was dried at $60^{\circ} \mathrm{C}$ until its mass was constant. A 500-mg aliquot of dry liver was microwave digested in $70 \%$ nitric acid for $45 \mathrm{~min}$ at $180 \mathrm{psi}$ in a microwave digester MDS2000 (CEM, Matthews, NC, USA). Lead concentrations were measured by Zeeman graphite furnace-atomic absorption spectroscopy on a 4100 ZL spectrometer (PerkinElmer, Norwalk, CT, USA). Our results from three replicates of a certified reference sample of bovine liver (BCR 185, Promochem, Wesel, Germany) with a mean \pm standard deviation of $501 \pm 38 \mathrm{ng} / \mathrm{g}$ dry weight were $540 \pm 14 \mathrm{ng} / \mathrm{g}$. Bones were cleaned of inserted muscles, oven dried to constant mass, and weighed to the nearest $0.1 \mathrm{mg}$. Each bone was then microwave digested and $\mathrm{Pb}$ concentrations were measured by inductively coupled plasma-atomic emission spectroscopy on an Optima 3000 spectrometer (Perkin-Elmer). Blood $\mathrm{Pb}$ concentration was determined in duplicates of each sample by a graphite furnace-atomic absorption spectroscopy on a GBC GF 2000 Controller spectrometer (GBC, Dandenong, Victoria, Australia) after dilution of $50 \mathrm{iil}$ of blood in 50 iil of Triton X-100 (1\%) and 150 iil of deionized water. Blood $\mathrm{Pb}$ concentration of each sample was obtained from the average of duplicates. Results from duplicate analyses, fortified samples, and reference samples of human blood (Lyphochek, Bio-Rad Laboratories, Richmond, CA, USA) with three levels of $\mathrm{Pb}(0.081$, 0.285 , and $0.541 \mathrm{iig} / \mathrm{ml}$ ) were within quality control guidelines. Minimum detection limits of $\mathrm{Pb}$ were $0.1 \mathrm{iig} / \mathrm{g}$ dry 
Table 1. Proportions of fully grown ducks from wetlands of Valencia and other parts of Spain containing ingested Pb shot in the gizzard and those above threshold levels of $\mathrm{Pb}$ exposure in liver and bone (humerus and/or femur); percentages are presented in parentheses

\begin{tabular}{|c|c|c|c|c|c|c|c|c|c|}
\hline & \multicolumn{3}{|c|}{$\mathrm{Pb}$ shot in gizzard } & \multicolumn{3}{|c|}{$\begin{array}{c}\text { Liver } \mathrm{Pb} \\
>5 \text { iig/g dry weight }^{\mathrm{a}}\end{array}$} & \multicolumn{3}{|c|}{$\begin{array}{c}\text { Bone } \mathrm{Pb} \\
>10 \text { iig/g dry weight }{ }^{\mathrm{b}}\end{array}$} \\
\hline & Valencia & Others & Total & Valencia & Others & Total & Valencia & Others & Total \\
\hline Marmaronetta angustirostris & $\begin{array}{l}21 / 50^{c} \\
(42)^{d}\end{array}$ & $\begin{array}{r}0 / 6 \\
(0)\end{array}$ & $\begin{array}{c}21 / 56 \\
(38)\end{array}$ & $\begin{array}{c}10 / 25 \\
(40)\end{array}$ & $\begin{array}{l}0 / 5 \\
(0)\end{array}$ & $\begin{array}{l}10 / 30 \\
(33)\end{array}$ & $\begin{array}{l}3 / 41 \\
(7)\end{array}$ & $\begin{array}{l}0 / 6 \\
(0)\end{array}$ & $\begin{array}{r}3 / 47 \\
(6)\end{array}$ \\
\hline Oxyura leucocephala & $\begin{array}{c}13 / 25 \\
(52)\end{array}$ & $\begin{array}{l}0 / 1 \\
(0)\end{array}$ & $\begin{array}{l}13 / 26 \\
(50)\end{array}$ & $\begin{array}{l}9 / 17 \\
(53)\end{array}$ & $\begin{array}{l}0 / 1 \\
(0)\end{array}$ & $\begin{array}{l}9 / 18 \\
(50)\end{array}$ & $\begin{array}{c}1 / 1 \\
(100)\end{array}$ & $\begin{array}{l}0 / 1 \\
(0)\end{array}$ & $\begin{array}{l}1 / 2 \\
(50)\end{array}$ \\
\hline Oxyura jamaicensis ${ }^{f}+$ hybrids $^{\mathrm{g}}$ & $\begin{array}{l}9 / 20 \\
(45)\end{array}$ & $\begin{array}{l}4 / 33 \\
(12)\end{array}$ & $\begin{array}{l}13 / 53 \\
(25)\end{array}$ & $\begin{array}{l}4 / 16 \\
(25)\end{array}$ & $\begin{array}{l}1 / 12 \\
(8)\end{array}$ & $\begin{array}{l}5 / 28 \\
(18)\end{array}$ & $\begin{array}{l}1 / 5 \\
(20)\end{array}$ & $\begin{array}{l}0 / 12 \\
(0)\end{array}$ & $\begin{array}{r}1 / 17 \\
(6)\end{array}$ \\
\hline Total Oxyura spp. & $\begin{array}{c}22 / 45 \\
(49)\end{array}$ & $\begin{array}{l}4 / 34 \\
(12)\end{array}$ & $\begin{array}{l}26 / 79 \\
(33)\end{array}$ & $\begin{array}{l}13 / 33 \\
(39)\end{array}$ & $\begin{array}{l}1 / 13 \\
(8)\end{array}$ & $\begin{array}{c}14 / 46 \\
(30)\end{array}$ & $\begin{array}{l}2 / 6 \\
(33)\end{array}$ & $\begin{array}{l}0 / 13 \\
(0)\end{array}$ & $\begin{array}{l}2 / 19 \\
(11)\end{array}$ \\
\hline
\end{tabular}

${ }^{\mathrm{a}}[5]$.

b $[23]$.

c Birds exposed $/ n$.

${ }^{\mathrm{d}}$ Percentage.

e White-headed duck.

${ }^{\mathrm{f}}$ Ruddy duck.

g Oxyura leucocephala $\mathrm{X}$ jamaicensis.

weight in liver of fully grown birds, $0.3 \mathrm{iig} / \mathrm{g}$ dry weight in liver of ducklings, $0.05 \mathrm{iig} / \mathrm{g}$ dry weight in bones, and 0.01 $\mathrm{iig} / \mathrm{ml}$ in blood samples. Birds were considered exposed to abnormal $\mathrm{Pb}$ levels with liver concentration >5 iig/g dry weight [5], bone concentration $>10 \mathrm{iig} / \mathrm{g}$ dry weight, and blood concentration $>0.2 \mathrm{iig} / \mathrm{ml}$ [23]. Those birds found dead with liver $\mathrm{Pb}$ concentrations $>20$ iig/g dry weight can be considered to have died by $\mathrm{Pb}$ poisoning and those with blood $\mathrm{Pb}$ concentrations $>1 \mathrm{iig} / \mathrm{ml}$ as severely poisoned [23].

\section{Statistical analyses}

Prevalences of Pb-shot ingestion and $\mathrm{Pb}$ concentrations above the chosen threshold levels were compared among species, locations, and collection method (shot or found dead) with Fisher exact tests. Generalized linear models (GLMs) were constructed using GLIM software [24] to investigate the factors explaining variation in presence or absence of $\mathrm{Pb}$ shot (as a binary variable) and the concentration of $\mathrm{Pb}$ in liver and bone tissue in fully grown birds. Lead-shot prevalence was analyzed using a binomial error and logit link function, while tissue concentrations were analyzed using normal error and identity link functions (log-transforming the dependent variable to remove heteroscedasticity). Predictors used in the models were region where the birds were collected (factor of two levels, Valencia or other areas), collection method used (factor, shot or found dead), sex (factor), and age (factor, adult or juvenile). Separate models were constructed for stifftails and marbled teal (excluding the three birds shot and the factor collection method from the latter models). Sample size varied considerably between models because not all tissues were analyzed in all birds and not all birds could be sexed or aged. We present the final models in which collection method (for stifftails) and region were included together with sex or age, when these had significant effects. We also present the partial effects of the nonsignificant variables when these were added to the final models.

In stifftails, the humerus was the only bone analyzed. In marbled teal, the humerus and/or the femur were analyzed. For the GLMs, we analyzed humerus concentrations or femur concentrations when the former were not measured. Preliminary analyses showed that there were no significant differences between these two measures in fully grown teal.
In order to study the relationship between $\mathrm{Pb}$ levels in tissues and the amount of $\mathrm{Pb}$ ingested, we used the number of $\mathrm{Pb}$ shot observed in the gizzard and the estimated mass of $\mathrm{Pb}$ eroded. The latter was calculated by subtracting the observed mass of the shot from the expected mass of uneroded shot (considered to be $128 \mathrm{mg}$ [2]). We added these variables to GLMs to identify their partial correlations with $\mathrm{Pb}$ tissue levels while controlling for region and collection method.

The $\mathrm{Pb}$ concentrations in teal tissues showed a log-normal distribution (confirmed with Kolmogorov-Smirnov tests) and comparisons between tissue levels within and among age classes (ducklings and fully grown birds) were made using logtransformed concentrations and $t$ tests. Pearson correlations among log-transformed $\mathrm{Pb}$ tissue concentrations were conducted for each age class. Because of the log-normal distribution of $\mathrm{Pb}$ concentrations, results are expressed with geometric means and 95\% confidence intervals (CI) rather than with arithmetic means.

Differences in the total weight of grit in the gizzard between taxa, sex, age, location, collection method, and the presence of ingested shot were studied with analyses of variances. Because of the unit-sum constraint of grit size fractions for each individual duck, differences in grit composition due to the above factors were studied by means of compositional analysis of the fractions as percentages, using a multiple analysis of variance of the log of the weight of each fraction divided by the weight of grit $<0.5 \mathrm{~mm}$ [22].

\section{RESULTS}

A high proportion of marbled teal and stifftails studied had ingested $\mathrm{Pb}$ shot or abnormal $\mathrm{Pb}$ concentrations in liver or bone tissues, particularly in Valencia (Table 1). Eighty percent of the white-headed ducks and $20 \%$ of the marbled teal found dead had lethal liver $\mathrm{Pb}$ concentrations (Fig. 2), and common necropsy findings in these birds were ingested $\mathrm{Pb}$ shot; weight loss; pale tissues; bile-stained gizzard, liver, and vent; and white streaks in the heart. Lead levels in the blood of eight white-headed ducks rescued from El Hondo, seven of them not included in Table 1, were all indicative of $\mathrm{Pb}$ poisoning (range 1.4-6.2 iig/ml) and all of them died within a few days of their admittance to the Center for Nature Protection and Study in Valencia. These birds showed weakness, bright green 

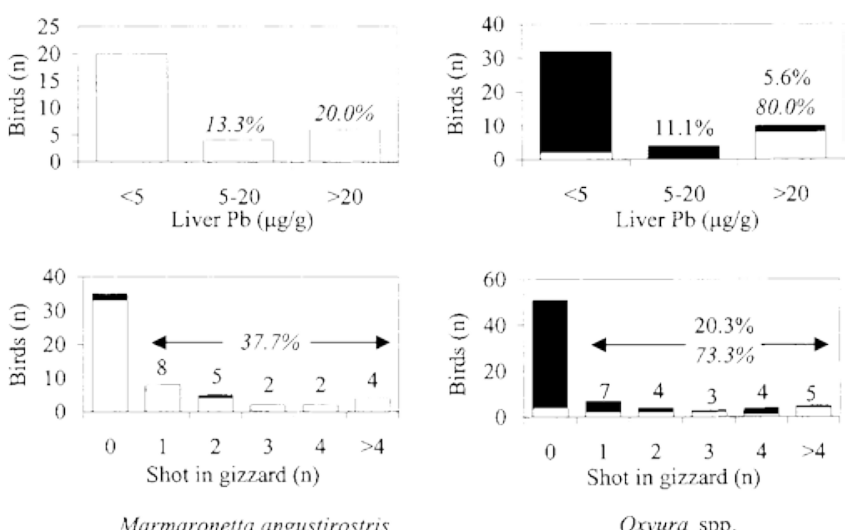

Marmaronetta angustirostris

Oxyura spp.

Fig. 2. Distribution of the number of ingested $\mathrm{Pb}$ shot and $\mathrm{Pb}$ liver concentrations in fully grown marbled teals and stifftails (Oxyura spp.) from Spain, separating birds shot (black bars) and those found dead or moribund (white bars). Percentages within two ranges of liver $\mathrm{Pb}$ concentration or with $\mathrm{Pb}$ shot in the gizzard are shown for birds shot (regular) and found dead (italics). Exact number of birds with different numbers of $\mathrm{Pb}$ shot in the gizzard are also shown.

diarrhea, paleness of mucous membranes, and low hematocrit (30-35\%).

The differences observed between taxa in prevalences were strongly influenced by the way the birds were collected (Fig. $2)$. Most of the fully grown marbled teal (95\%, 56 of 59) and $69 \%$ (20 of 29) of white-headed ducks were found dead, whereas $98 \%$ (53 of 54 ) of ruddy ducks and hybrids were shot. Thus, the data in Table 1 for marbled teal and white-headed duck are likely to exaggerate the prevalence of $\mathrm{Pb}$ exposure in their populations because they are mainly birds found dead, whereas the data for ruddy ducks and hybrids, mainly shot, are likely to reflect more accurately the prevalences in the group of the stifftails. For example, 70\% (14 of 20) of stifftails found dead in Valencia had ingested $\mathrm{Pb}$ shot, compared with only 32\% (8 of 25) stifftails shot in this region (Fisher exact, $p<0.017$ ), and similar differences were observed for all areas combined (Fig. 2). Liver $\mathrm{Pb}$ concentrations suggest that $\mathrm{Pb}$-shot ingestion is more likely to be a direct cause of mortality for stifftails than for marbled teal (Fig. 2). Among birds found dead in Valencia, 43\% of marbled teal (20 of 47) had ingested Pb shot, compared with $70 \%$ of stifftails (14 of 20) (Fisher exact, $p=$ 0.06). Similarly, $40 \%$ of these marbled teal (10 of 25) had $\mathrm{Pb}$ liver concentrations over $5 \mathrm{iig} / \mathrm{g}$, compared with $80 \%$ of stifftails (8 of 10) (Fisher exact, $p=0.06$ ).

The GLMs showed that the proportion of stifftails containing ingested $\mathrm{Pb}$ shot was significantly higher in Valencia, higher in birds found dead than those shot (Fig. 2), and lower in adults than in juveniles (Table 2). For marbled teal, the prevalence of ingested $\mathrm{Pb}$ shot was also significantly higher in Valencia, but there were no age or sex effects (Table 2).

The $\mathrm{Pb}$ concentrations in liver were significantly higher in stifftails found dead than in shot birds (Fig. 2), but the regional and age effects were not significant (Table 3). In marbled teal, no predictor variables had a significant effect on liver concentrations (Table 3), although they were marginally higher in Valencia $(p<0.08)$. The GLMs for $\mathrm{Pb}$ bone concentrations revealed rather different patterns. In stifftails, concentrations were significantly higher in Valencia and in females (Table 4). The data suggest that, for a given exposure to ingested $\mathrm{Pb}$ shot, female stifftails deposit more $\mathrm{Pb}$ in bone than males. Even when controlling for the number of ingested $\mathrm{Pb}$ shot (i.e., adding this predictor to the model of Table 4), females still had higher $\mathrm{Pb}$ levels in bone than males $\left(F_{1,14}=4.84, p<\right.$ $0.05)$. In marbled teal, bone concentrations were higher in adults than in juveniles (Table 4).

Although not included in the models presented in Tables 3 and 4 , the amount of $\mathrm{Pb}$ shot found in the gizzard is a strong predictor of the $\mathrm{Pb}$ concentration in liver and bone tissues, confirming ingested shot as the primary source of contamination. While controlling for region (plus collection method for stifftails) in GLMs, both number of ingested shot in the gizzard and eroded mass of $\mathrm{Pb}$ showed strong partial corre-

Table 2. Generalized linear models ${ }^{\mathrm{a}}$ of Pb-shot prevalence in the gizzards of fully grown marbled teal (Marmaronetta angustirostris) and stifftails (Oxyura spp.)

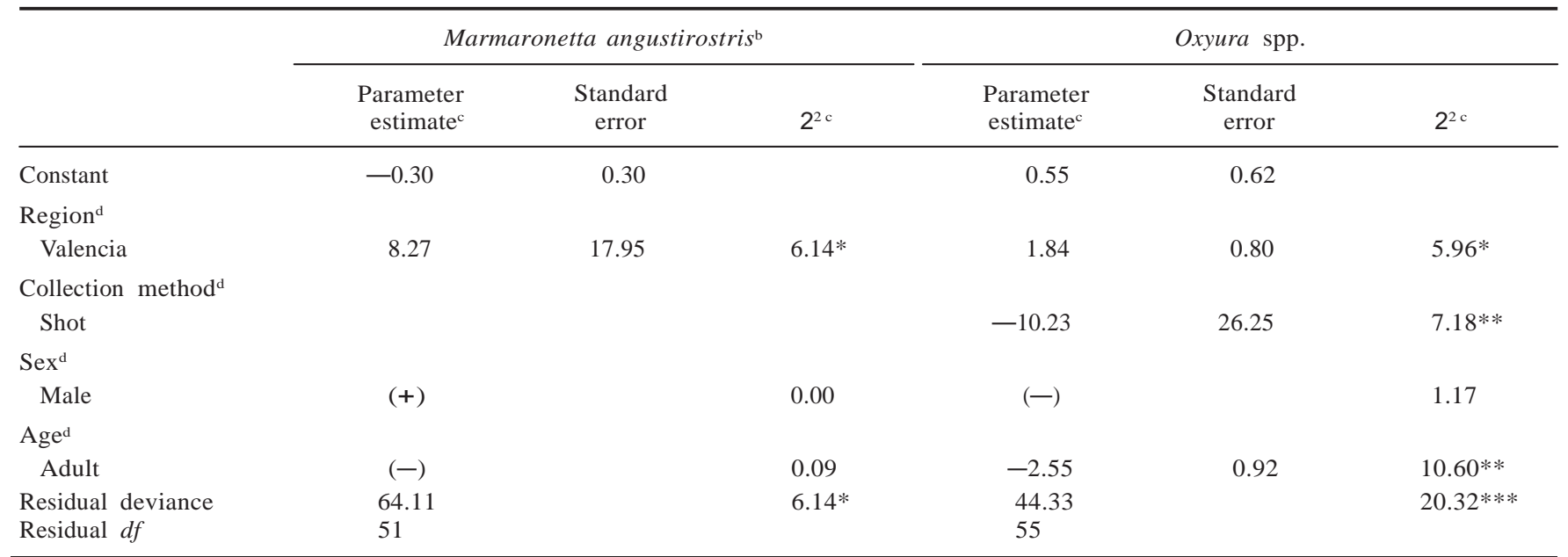

\footnotetext{
a The dependent variable was one (when shot were present) or zero, using a binomial error and a logit link function.

b Collection method was excluded from the teal model.

c Partial $2^{2}$ values and the sign of the parameter estimate (in parentheses) are shown for independent variables excluded from the final models.

${ }^{\mathrm{d}}$ Region other, collection method found dead, sex female, and age juvenile were aliased.

$* p<0.05$.

** $p<0.01$.

*** $p<0.001$.
} 
Table 3. Generalized linear models ${ }^{\mathrm{a}}$ of $\mathrm{Pb}$ liver concentration (expressed as $\ln [$ concn. in ng/g dry weight +2 ]) of fully grown marbled teal (Marmaronetta angustirostris) and stifftails (Oxyura spp.)

\begin{tabular}{|c|c|c|c|c|c|c|}
\hline & \multicolumn{3}{|c|}{ Marmaronetta angustirostris ${ }^{\mathrm{b}}$} & \multicolumn{3}{|c|}{ Oxyura spp. } \\
\hline & $\begin{array}{c}\text { Parameter } \\
\text { estimate }^{c}\end{array}$ & $\begin{array}{l}\text { Standard } \\
\text { error }\end{array}$ & $F$ ratio $^{c}$ & $\begin{array}{l}\text { Parameter } \\
\text { estimate }^{c}\end{array}$ & $\begin{array}{l}\text { Standard } \\
\text { error }\end{array}$ & $F$ ratio $^{c}$ \\
\hline Constant & 7.94 & 0.49 & & 6.71 & 0.36 & \\
\hline \multicolumn{7}{|l|}{ Region $^{\mathrm{d}}$} \\
\hline Valencia & 2.20 & 1.20 & 3.34 & 0.63 & 0.60 & 1.12 \\
\hline \multicolumn{7}{|l|}{ Collection method ${ }^{\mathrm{d}}$} \\
\hline Shot & & & & -4.01 & 0.65 & $37.67 * * *$ \\
\hline \multicolumn{7}{|l|}{$\operatorname{Sex}^{\mathrm{d}}$} \\
\hline Male & $(+)$ & & 0.05 & $(-)$ & & 0.04 \\
\hline \multicolumn{7}{|l|}{$\operatorname{Age}^{\mathrm{d}}$} \\
\hline Adult & $(-)$ & & 0.25 & $(-)$ & & 1.30 \\
\hline Residual deviance & 168.51 & & 3.34 & 128.19 & & $24.19 * * *$ \\
\hline Residual $d f$ & 28 & & & 43 & & \\
\hline
\end{tabular}

${ }^{a}$ Using a normal error and identity link function.

${ }^{\mathrm{b}}$ Collection method was excluded from the teal model.

c Partial $F$ values and the sign of the parameter estimate (in parentheses) are shown for independent variables excluded from the final models.

${ }^{\mathrm{d}}$ Region other, collection method found dead, sex female, and age juvenile were aliased.

$* * * p<0.001$.

lations with the $\mathrm{Pb}$ concentrations in liver of stifftails $(r=$ 0.48, $F_{1,39}=11.8, p=0.0014$; and $r=0.52, F_{1,39}=14.4, p$ $=0.0005$, respectively) and marbled teal $\left(r=0.47, F_{1,27}=\right.$ 7.6, $p<0.011$; and $r=0.49, F_{1,39}=8.4, p<0.008$, respectively). The equivalent partial correlations of $\mathrm{Pb}$ concentrations in bone tissue with the number of ingested shot and the eroded mass of $\mathrm{Pb}$ were even stronger in stifftails $\left(r=0.82, F_{1,15}=\right.$ 30.4, $p<0.0001$; and $r=0.88, F_{1,15}=49.2, p<0.0001$, respectively) and marbled teal $\left(r=0.56, F_{1,41}=18.4, p=\right.$ 0.0001 ; and $r=0.56, F_{1,41}=18.4, p=0.0001$, respectively).

Major differences were observed in tissue concentrations between ducklings and fully grown marbled teal (Table 5). Since the presence of ingested $\mathrm{Pb}$ shot in the gizzard is a major determinant of $\mathrm{Pb}$ concentrations, we excluded birds with in- gested shot from statistical comparisons of tissue concentrations among and within age groups. Ingested $\mathrm{Pb}$ shot was only recorded in one marbled teal chick, a bird of intermediate age (class II). Liver $\mathrm{Pb}$ concentrations were higher in fully grown birds than in ducklings, but the reverse was true for both humerus and femur (Table 5). Humerus $\mathrm{Pb}$ concentrations in marbled teal ducklings, although adjusted to a log-normal distribution, showed high dispersion (Table 5), and two groups of ducklings are apparent. In eight birds, $\mathrm{Pb}$ concentration was

$4 \mathrm{iig} / \mathrm{g}$ dry weight, and in the other six birds, the values ranged from 8 to $26.6 \mathrm{iig} / \mathrm{g}$ dry weight, the latter possibly corresponding to ducklings whose mothers were exposed to $\mathrm{Pb}$ shot prior to or during clutch formation. However, this bimodal distribution was not observed in femur $\mathrm{Pb}$ concen-

Table 4. Generalized linear models ${ }^{\mathrm{a}}$ of $\mathrm{Pb}$ concentration in humerus or femur (expressed as ln[concn. in iig/g dry weight +0.002$]$ ) of fully grown marbled teal (Marmaronetta angustirostris) and stifftails (Oxyura spp.)

\begin{tabular}{|c|c|c|c|c|c|c|}
\hline & \multicolumn{3}{|c|}{ Marmaronetta angustirostris ${ }^{\mathrm{b}}$} & \multicolumn{3}{|c|}{ Oxyura spp. } \\
\hline & $\begin{array}{l}\text { Parameter } \\
\text { estimate }^{c}\end{array}$ & $\begin{array}{l}\text { Standard } \\
\text { error }\end{array}$ & $F$ ratio $^{c}$ & $\begin{array}{c}\text { Parameter } \\
\text { estimate }^{c}\end{array}$ & $\begin{array}{l}\text { Standard } \\
\text { error }\end{array}$ & $F$ ratio $^{c}$ \\
\hline Constant & 1.01 & 0.08 & & 1.79 & 0.14 & \\
\hline \multicolumn{7}{|l|}{ Region $^{\mathrm{d}}$} \\
\hline Valencia & 0.19 & 0.13 & 2.16 & 0.82 & 0.16 & $26.68 * * *$ \\
\hline \multicolumn{7}{|l|}{ Collection method ${ }^{\mathrm{d}}$} \\
\hline Shot & & & & 0.18 & 0.39 & 0.22 \\
\hline \multicolumn{7}{|l|}{$\operatorname{Sex}^{\mathrm{d}}$} \\
\hline Male & $(+)$ & & 0.25 & -1.91 & 0.31 & $38.18 * * *$ \\
\hline \multicolumn{7}{|l|}{$\operatorname{Age}^{d}$} \\
\hline Adult & 0.23 & 0.11 & $4.39 *$ & $(+)$ & & 0.01 \\
\hline Residual deviance & 1.83 & & $3.78 *$ & 1.14 & & $55.55^{* * *}$ \\
\hline Residual $d f$ & 22 & & & 15 & & \\
\hline
\end{tabular}

a Using a normal error and identity link function.

b Collection method was excluded from the teal model.

c Partial $F$ values and the sign of the parameter estimate (in parentheses) are shown for independent variables excluded from the final models.

${ }^{\mathrm{d}}$ Region other, collection method found dead, sex female, and age juvenile were aliased.

$* p<0.05$.

*** $p<0.001$. 
Table 5. Lead concentrations (iig/g dry wt) in tissues of marbled teal (Marmaronetta angustirostris) without ingested $\mathrm{Pb}$ shot

\begin{tabular}{llcc}
\hline & & Ducklings & Fully grown \\
\hline Liver & $n$ & 16 & 20 \\
& $\mathrm{GM}^{\mathrm{a}}$ & $0.21^{\mathrm{bc}}$ & 0.75 \\
Humerus & $95 \% \mathrm{CI}$ & $0.15-0.28$ & $0.34-1.64$ \\
& $n$ & 14 & 27 \\
Femur & GM & $4.32^{\mathrm{b}}$ & 0.68 \\
& $95 \% \mathrm{CI}$ & $1.91-9.79$ & $0.45-1.01$ \\
& $n$ & 12 & 25 \\
& GM & $2.71^{\mathrm{b}}$ & 0.62 \\
\hline
\end{tabular}

a Geometric mean (i.e., mean of the log-transformed distribution).

b Significantly different from concentrations in the same tissue of fully grown birds (Student's $t$ tests, $p<0.01$ ).

c Significantly different from humerus and femur concentration in ducklings (paired $t$ tests, $p<0.001$ ). No significant differences were found between different tissue concentrations in fully grown teal or between humerus and femur concentrations in ducklings.

trations. In ducklings, higher $\mathrm{Pb}$ concentrations were found in bones than in liver (humerus vs liver, $n=14$, geometric means $=4.32$ vs 0.22 ; femur vs liver, $n=12$, geometric means $=$ 2.71 vs 0.19 ; paired $t$ tests, $p<0.001$ ), but there were no such differences in fully grown birds (Table 5).

Correlations among $\mathrm{Pb}$ concentrations in liver, humerus, and femur were significant for fully grown teal (liver with humerus: $n=21, r=0.581, p=0.005$; liver with femur: $n$ $=16, r=0.503, p=0.046$; humerus with femur: $n=34, r$ $=0.678, p<0.001)$ but not for the ducklings $(p>0.05)$. Liver and humerus $\mathrm{Pb}$ concentrations were also correlated in stifftails ( $n=19, r=0.633, p=0.003$ ).

Grit size composition was different between fully grown marbled teal and stifftails (Wilk's $X=0.49, F_{5,116}=24.12, p$ $<0.0001$ ), stifftails selecting grit more similar in size to $\mathrm{Pb}$ shot (Fig. 3). Grit size composition was different between Valencia and other regions (marbled teal: Wilk's $X=0.77$, $F_{5,49}=2.87, p=0.0236$; stifftails: Wilk's $X=0.83, F_{5,61}=$ 2.56, $p=0.036$ ), with smaller proportions of coarse grit in Valencia, especially in the teal (Fig. 3). The total mass of grit was higher in stifftails than in teal $\left(F_{1,126}=4.744, p=0.031\right)$ and lower for both taxa in Valencia $\left(F_{1,126}=9.81, p=0.0022\right)$. Mean mass \pm standard error of grit in stifftails was $0.79 \pm$ $0.13 \mathrm{~g}$ in Valencia $(n=40)$ and $1.23 \pm 0.12 \mathrm{~g}$ in other areas $(n=34)$. Mass of grit in marbled teal was $0.44 \pm 0.04 \mathrm{~g}$ in Valencia $(n=50)$ and $0.93 \pm 0.19 \mathrm{~g}$ in other areas $(n=6)$. No significant differences were observed in the total amount or size composition of grit between collection methods, the presence or absence of ingested shot, sex, or age or between
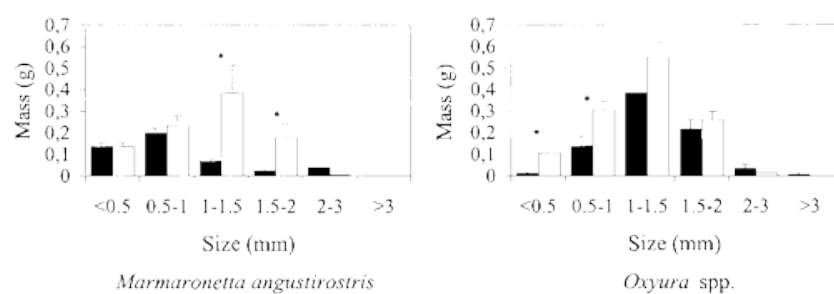

Fig. 3. Mass of the different grit size categories from the gizzards of fully grown marbled teals and stifftails (Oxyura spp.) from Valencia (black bars) and other regions in Spain (white bars). Significant differences in the mass of fractions between areas are marked with asterisks (analysis of variance, $p<0.05$ ). different stifftail taxa. Marbled teal ducklings had no measurable grit.

\section{DISCUSSION}

Previous studies of $\mathrm{Pb}$ poisoning in the Mediterranean part of Europe showed it to be a major problem for relatively widespread, abundant species of waterfowl wintering in the region but breeding further north [2-6]. Ours is the first study to focus on waterfowl species resident in the Mediterranean region and shows, based on clinical signs, necropsy findings, and liver $\mathrm{Pb}$ concentrations, that $\mathrm{Pb}$ poisoning is a cause of mortality [23] in two globally threatened species in Spain, especially in El Hondo and other wetlands in the Valencian community where both marbled teal and white-headed duck have become increasingly concentrated over the past decade [15]. Other waterfowl species of conservation concern are likely to be similarly affected by $\mathrm{Pb}$ poisoning in Mediterranean wetlands. During the course of our study, we analyzed one ferruginous duck (Aythya nyroca), a species close to extinction in Spain and considered near threatened at a global level [13]. This bird, found dead at El Hondo on February 29, 1997, had 30 ingested $\mathrm{Pb}$ shot.

Marbled teal and stifftails collected in Valencia had significantly more ingested $\mathrm{Pb}$ shot than those collected elsewhere, as was expected given the higher densities of shot in Valencian wetlands (range of means: 124-288 shot $/ \mathrm{m}^{2}$ ) compared with the Doñana wetlands in Andalucía (maximum mean: $14 \mathrm{shot} / \mathrm{m}^{2}$ ), one of our other study areas [6]. The prevalences of Pb-shot ingestion in other waterfowl species in Valencian wetlands are among the highest recorded in Spain [6], and epizootics of $\mathrm{Pb}$ poisoning in greater flamingos (Phoenicopterus ruber roseus) have occurred annually over the last decade in El Hondo [21]. Bone $\mathrm{Pb}$ concentration was higher in stifftails from Valencia, reflecting the higher rate of shot ingestion in that wetland. Low calcium intake may also increase $\mathrm{Pb}$ deposition in bones [25], and grit, an important source of calcium, is scarce in these wetlands [6].

Our results suggest that stifftails were more affected by $\mathrm{Pb}$ poisoning than marbled teal. The lower prevalence of ingested shot and $\mathrm{Pb}$ levels in liver in stifftails that were shot was expected since many birds found dead had apparently died of $\mathrm{Pb}$ poisoning. However, $\mathrm{Pb}$ exposure in shot birds was still commonplace (e.g., 32\% of stifftails shot in Valencia had ingested shot). The prevalence of ingested $\mathrm{Pb}$ shot in stifftails shot may even underestimate the exposure of white-headed ducks to $\mathrm{Pb}$ since most birds collected by shooting were ruddy ducks or hybrids that were killed as soon as possible after they were first observed at the site [14]. They are thus likely to have been newly arrived or newly fledged birds having had less time exposed to the high $\mathrm{Pb}$-shot densities at sites such as El Hondo than the average white-headed duck. The time of residence in an area can affect the risk of $\mathrm{Pb}$-shot ingestion in waterfowl [26,27]. Among Australian waterfowl, two stifftails, the blue-billed duck (Oxyura australis) and the musk duck (Biziura lobata), appear to be the species most affected by $\mathrm{Pb}$ exposure, with 24 and $50 \%$ of individuals, respectively, showing elevated levels in bone [28]. Few data exist on the prevalence of shot ingestion in ruddy ducks in their natural range in North America, but these suggest they are as susceptible to $\mathrm{Pb}$ exposure as other diving ducks [10], which tend to be more affected than dabbling ducks because they can easily reach $\mathrm{Pb}$ shot present at the bottom of wetlands [8].

Given that almost all our fully grown marbled teal were 
found dead (i.e., the absence of a less biased sample collected by shooting), it is harder to assess the true prevalence of $\mathrm{Pb}$ exposure in this species. However, this prevalence must be relatively high given that the proportion of the marbled teal population that died in the epizootic of organophosphate poisoning and botulism at El Hondo in 1997 that provided most of our sample was at least $25 \%$, and possibly over $50 \%$. Thus, even in the unlikely event that all individuals exposed to $\mathrm{Pb}$ shot died in the epizootic, the overall prevalence of ingested shot in the El Hondo population would still have been at least $11 \%$ at that point in time (we found a prevalence of $45 \%$ in the 44 individuals collected in the 1997 epizootic, but at least 150 teal died from an estimated total of 600). The marbled teal in Spain has a particularly high annual mortality rate [29], and $\mathrm{Pb}$ poisoning is likely to be one factor responsible, exacerbating its threatened status.

Overall, stifftails selected more and larger grit sizes than marbled teal, a result consistent with the obser ved difference in $\mathrm{Pb}$-shot exposure. In confusion, waterfowl select $\mathrm{Pb}$ shot for large grit particles [30]. The amounts of grit selected approximately 1 to $2 \mathrm{~mm}$ in diameter by both taxa were similar to those selected by other waterfowl species showing high prevalences of $\mathrm{Pb}$-shot ingestion of 28 to $74 \%$ in the Ebro delta, another Spanish Mediterranean wetland [22]. The regional differences we found in grit selection may be a product of differences in grit availability. In both taxa, birds collected in El Hondo had a smaller proportion of coarse grit, where the particles of grit $>0.5 \mathrm{~mm}$ constitute only $0.86 \%$ of the total weight of sediment, while in other Spanish wetlands, they constitute 1.5 to $13.4 \%$ [6]. Some regional variation in stifftail diet has been recorded in Spain [18], and changes in diet could affect grit requirements and selection [30]. The marbled teal collected in Valencia were feeding mainly on Scirpus litoralis seeds, while those collected elsewhere were feeding mainly on Ruppia maritima seeds (A.J. Green, unpublished data). These seeds are similar in size but may vary in hardness, $R$. maritima possibly requiring larger grit to break them up.

Adult stifftails had a lower prevalence of ingested shot than juveniles, perhaps due to the foraging inexperience of juvenile birds that increases their likelihood of ingesting shot [26,31]. Alternatively, the higher Pb-shot ingestion in juvenile stifftails may reflect the fact that a higher proportion of adults were ruddy ducks (49\%, compared with $30 \%$ of juveniles). Some ruddy ducks were collected from northern Spanish wetlands (Fig. 1), which perhaps have particularly low shot densities. Others shot on Mediterranean wetlands had probably arrived from further north in Europe shortly before being shot [14], thus having less time to ingest $\mathrm{Pb}$ shot than the white-headed ducks or hybrids native to these wetlands with high $\mathrm{Pb}$-shot densities. This could explain why we found differences in $\mathrm{Pb}$ shot prevalence between age classes in the absence of any differences in grit size selection. Other studies have found no age-related differences in the prevalence of shot ingestion $[3,7,32]$ or have observed higher prevalences of Pb-shot ingestion [8] or elevated blood $\mathrm{Pb}$ [33] in adults.

Major differences within and between taxa were observed in the predictors of variation in $\mathrm{Pb}$-shot ingestion and $\mathrm{Pb}$ concentrations in liver and bone. From a statistical perspective, it is difficult to assess which of the differences between analyses are reliable since the data set for each analysis was somewhat different (since not all tissues were analyzed in all birds and not all birds could be aged or sexed) and the measurement error for each dependent variable is likely to differ somewhat. For example, the only significant effect of sex was observed in stifftail bones, yet less than a third $(n=19)$ of all stifftails were included in this data set, of which only two were females, both of which showed extremely high levels. Differences in $\mathrm{Pb}$-shot ingestion or tissue concentrations related to sex have been described in several studies of different species, but this is far from being a general pattern [1,3,7,10,26,32,34,35]. Experimental studies suggest that the higher bone $\mathrm{Pb}$ concentration in females could be related to calcium requirements and to the active bone metabolism during egg laying [25,35,36]. However, White and Stendell [34] did not find differences in bone $\mathrm{Pb}$ concentrations in a field study with mallard, northern pintail, and black duck, and sexual differences in absorption rates may not exist outside the breeding season [37] or may even be higher in males [38].

No data are available on $\mathrm{Pb}$ concentrations in eggs of marbled teal from El Hondo, but a transfer of $\mathrm{Pb}$ from exposed hens to their eggs and the high deposition of $\mathrm{Pb}$ following the calcium pathway for bone formation in chicks [25,39] may explain the high $\mathrm{Pb}$ bone levels in teal ducklings. However, in fully grown teal with bones that have reached full size, juveniles had lower bone $\mathrm{Pb}$ concentrations than adults, possibly due to the dilution of maternal $\mathrm{Pb}$ in the larger bones of juveniles compared with ducklings [35] and also to the longterm exposure of adults to $\mathrm{Pb}$ shot. Given their young age $(<9$ $\mathrm{d}), \mathrm{Pb}$ in teal ducklings probably came from the eggs or from ingested food or sediment but is not likely to have come from ingested $\mathrm{Pb}$ shot or grit because none was observed in their gizzards. From the bimodal distribution observed in humerus $\mathrm{Pb}$ concentration, we estimate that $42 \%$ of ducklings may have been young of $\mathrm{Pb}$-exposed females. The relationship among the ducklings analyzed and the $\mathrm{Pb}$ levels in their mothers are unknown, so this percentage may not accurately reflect exposure levels for breeding female teal. Transfer of $\mathrm{Pb}$ from females to chicks has been demonstrated in doves [39], although accumulation of $\mathrm{Pb}$ in eggs is variable [35].

In fully grown birds, we found significant correlations between $\mathrm{Pb}$ concentrations in different tissues and significant partial correlations of these tissue concentrations with $\mathrm{Pb}$-shot ingestion. As expected, stronger correlations were observed between humerus and femur than between either bone and liver in fully grown teal. However, the number of $\mathrm{Pb}$ shot ingested and the mass of shot eroded showed stronger partial correlations with bone than with liver $\mathrm{Pb}$ concentrations for both teal and stifftails. These results were unexpected and may be partly due to the fact that sample sizes were different for the analyses of liver and bone concentrations. Furthermore, these partial $r$ values were heavily influenced by the other variables included in the GLM model. Thus, when sex was added to the bone model for stifftails, the partial $r$ values were reduced to 0.58 for the eroded mass of $\mathrm{Pb}$ and 0.36 for the number of ingested shot. When age was added to the marbled teal bone model, the $r$ values were reduced to 0.002 for both. Direct relationships between $\mathrm{Pb}$-shot ingestion and bone $\mathrm{Pb}$ concentrations have only been found in other studies when comparing populations [34] and are usually weak [40] because the bone $\mathrm{Pb}$ concentration tends to reflect long-term exposure rather than the acute high-level exposure reflected in liver concentrations [23]. The finding that adult marbled teal accumulate more $\mathrm{Pb}$ in bone than juveniles could reflect this long-term exposure to $\mathrm{Pb}$, as observed in other studies $[37,38]$. Our strong partial correlations between $\mathrm{Pb}$-shot ingestion and bone $\mathrm{Pb}$ are also 
probably related to the rapid hunting of ruddy ducks and hybrids upon their appearance in Spain and to the presence of so many juvenile teal (c.65\%) fledged in the weeks just before the epizootic in El Hondo. For these reasons, bone $\mathrm{Pb}$ concentrations were relatively low compared with other studies $[38,40]$ or similar to those observed in immature birds of about $1 \mathrm{iig/g}$ dry weight [37] and therefore may better reflect recent exposure to $\mathrm{Pb}$ shot.

Conservation measures are urgently required to reduce the major impact that $\mathrm{Pb}$ exposure is having on waterfowl in Spain, particularly the globally threatened marbled teal and whiteheaded duck. About 5.5\% of the shot stifftails showed liver $\mathrm{Pb}$ concentrations compatible with severe clinical poisoning (>20 iig/g dry wt) [23], and a monthly mortality rate of $7.4 \%$ could be estimated from the number of ingested $\mathrm{Pb}$ shot in the gizzard, as calculated by Bellrose [1] for mallards. Although our results suggest that $\mathrm{Pb}$ poisoning is more frequent in the white-headed duck, the additive effect of this problem may be more significant for the marbled teal. While the Spanish (but not the global) white-headed duck population has increased in the last 20 years[17], the Spanish marbled teal breeding population is smaller, is relatively more dependent on the highly contaminated El Hondo, and is undergoing a long-term decline [15]. It is important that the use of $\mathrm{Pb}$ shot in hunting activity in Spain be banned as soon as possible and that the most highly contaminated parts of El Hondo and other important wetlands be cleaned of $\mathrm{Pb}$ shot to prevent die-offs of waterfowl of all species.

Acknowledgement-Funding support was provided by the authors' institutes and the Humane Society. J. McCoy, J.C. Dolz, M. Gimenez, M. Máñez, J.D. Navarro, P. Pereira, H. Quebedeaux, N. Selva, C. Suarez, and C. Urdiales assisted in preparation of specimens and analysis of samples. N.W. Beyer and D.J. Pain provided helpful comments on the manuscript.

\section{REFERENCES}

1. Bellrose FC. 1959. Lead poisoning as a mortality factor in waterfowl populations. Ill Nat Hist Surv Bull 27:235-288.

2. Mateo R, Martínez-Vilalta A, Guitart R. 1997. Lead shot pellets in the Ebro delta, Spain: Densities in sediments and prevalences of exposure in waterfowl. Environ Pollut 96:335-341.

3. Pain DJ. 1990. Lead shot ingestion by waterbirds in the Camargue, France: An investigation of levels and interspecific differences. Environ Pollut 66:273-285.

4. Pain DJ, Handrinos GI. 1990. The incidence of ingested lead shot in ducks of the Evros delta, Greece. Wildfowl 41:167-170.

5. Guitart R, To-Figueras J, Mateo R, Bertolero A, Cerradelo S, Martínez-Vilalta A. 1994. Lead poisoning in waterfowl from the Ebro delta, Spain: Calculation of lead exposure thresholds for mallards. Arch Environ Contam Toxicol 27:289-293.

6. Mateo R, Belliure J, Dolz JC, Aguilar-Serrano JM, Guitart R. 1998. High prevalences of lead poisoning in wintering waterfowl in Spain. Arch Environ Contam Toxicol 35:342-347.

7. Mudge GP. 1983. The incidence and significance of ingested lead pellet poisoning in British wildfowl. Biol Conserv 27:333-372.

8. Sanderson GC, Bellrose FC. 1986. A review of the problem of lead poisoning in waterfowl. Ill Nat Hist Surv Spec Pub 4:1-34.

9. Daury RW, Schwab FE, Bateman MC. 1994. Prevalence of ingested lead shot in American black duck, Anas rubripes, and ring-necked duck, Aythya collaris, gizzards from Nova Scotia and Prince Edward Island. Can Field-Nat 108:26-30.

10. Fisher FM, Hall SL, Wilder WR, Robinson BC, Lobpries DS. 1986. An evaluation of spent shot ingestion in Texas wintering waterfowl by x-ray radiography. In Feierabend JS, Russell AB, eds, $\mathrm{Pb}$ Poisoning in Wild Waterfowl-A Workshop. National Wildlife Federation, Washington, DC, USA, pp 18-26.

11. Pirot JY, Taris JP. 1987. Le saturnisme des anatides hivernant en
Camargue: Réactualisation de données. Gibier Faune Sauvage 4:83-94.

12. Delany S, Reyes C, Hubert E, Pihl S, Rees E, Haanstra L, van Strien A. 1999. Results from the International Waterbird Census in the Western Palearctic and Southwest Asia 1995 and 1996. Wetlands International Publication 54. Wetlands International, Wageningen, The Netherlands.

13. BirdLife International. 2000. Threatened Birds of the World. Lynx Edicions and BirdLife International, Barcelona, Spain.

14. Heredia B, Rose L, Painter M, eds. 1996. Globally Threatened Birds in Europe. Action Plans. Council of Europe Publishing, Strasbourg, France.

15. Green AJ, Navarro JD. 1997. National censuses of the marbled teal, Marmaronetta angustirostris, in Spain. Bird Study 44:8087.

16. Green AJ, El Hamzaoui M. 2000. Diurnal behaviour and habitat use of non-breeding marbled teal, Marmaronetta angustirostris. Can J Zool 78:2112-2118.

17. Torres JA, Alcalá-Zamora A. 1997. Seguimiento de la población española de Malvasía Cabeciblanca (Oxyura leucocephala) durante los años 1996 y 1997. Oxyura 9:85-99.

18. Sánchez M, Green AJ, Dolz JC. 2000. The diets of the whiteheaded duck Oxyura leucocephala, ruddy duck O. jamaicensis and their hybrids from Spain. Bird Study 47:275-284.

19. Larson JS, Taber RD. 1980. Criteria of sex and age. In Schemnitz SD, ed, Wildlife Management Techniques Manual. Wildlife Society, Washington DC, USA, pp 143-202.

20. Green AJ, Navarro JD, Dolz JC, Aragoneses J. 1999. Brood emergence patterns in a Mediterranean duck community. Bird Study 46:116-118

21. Mateo R, Dolz JC, Aguilar-Serrano JM, Belliure J, Guitart R. 1997. An outbreak of lead poisoning in greater flamingos Phoenicopterus ruber roseus in Spain. J Wildl Dis 33:131-134.

22. Mateo R, Guitart R, Green AJ. 2000. Determinants of lead shot, rice and grit ingestion in ducks and coots. $J$ Wildl Manag 64: 939-947.

23. Pain DJ. 1996. Lead in waterfowl. In Beyer WN, Heinz GH, RedNorwood AW, eds, Environmental Contaminats in Wildlife: Interpreting Tissue Concentrations. Lewis, Boca Raton, FL, USA, pp 251-264.

24. Crawley MJ. 1993. GLIM for Ecologists. Blackwell Scientific, Oxford, UK.

25. Scheuhammer AC. 1996. Influence of reduced dietary calcium on the accumulation and effects of lead, cadmium, and aluminum in birds. Environ Pollut 94:337-343.

26. Hohman WL, Pritchert RD, Pace RM III, Woolington DW, Helm R. 1990. Influence of ingested lead on body mass of wintering canvasbacks. J Wildl Manag 54:211-215.

27. Flint PL, Petersen MR, Grand JB. 1997. Exposure of spectacled eiders and other diving ducks in western Alaska. Can J Zool 75: 439-443.

28. Norman FI, Garnham JS, Lowe KW. 1993. Further notes on lead concentrations in tissues of waterfowl in Victoria. Wildl Res 20: 621-624.

29. Green AJ. 2000. The habitat requirements of the marbled teal (Marmaronetta angustirostris), Ménétr, a review. In Comín FA, Herrera JA, Ramírez J, eds, Limnology and Aquatic Birds: Monitoring, Modelling and Management. Proceedings, 2nd International Symposium on Limnology and Aquatic Birds, Universidad Autónoma del Yucatán, Mérida, México, November 2427, 1997, pp 147-163.

30. Trost RE. 1981. Dynamics of grit selection and retention in captive mallards. J Wildl Manag 45:64-73.

31. Wheeler WE, Gates RJ. 1999. Spatial and temporal variation in lead levels related to body condition in the Mississippi Valley population of Canada geese. J Wildl Dis 35:178-186.

32. Havera SP, Whitton RM, Shealy RT. 1992. Blood lead and ingested and embedded shot in diving ducks during spring. $J$ Wildl Manag 56:539-545.

33. Samuel MD, Bowers EF, Franson JC. 1992. Lead exposure and recovery rates of black ducks banded in Tennessee. $J$ Wildl Dis 28:555-561. 
34. White DH, Stendell RC. 1977. Waterfowl exposure to lead and steel shot on selected hunting areas. J Wildl Manag 41:469-475.

35. Franson JC, Petersen MR, Creekmore LH, Flint PL, Smith MR. 1998. Blood lead concentrations of spectacled eiders near the Kashunuk River, Yukon Delta National Wildlife Refuge, Alaska. Ecotoxicology 7:175-181.

36. Finley MT, Dieter MP. 1978. Influence of laying on lead accumulation in bone of mallard ducks. J Toxicol Environ Health 4: 123-129.

37. Stendell RC, Smith RI, Burnham KP, Christensen RE. 1979. Exposure of waterfowl to lead: A nationwide survey of residues in wingbones of seven species, 1972-73. Scientific Report-Wild- life 223. U.S. Department of the Interior, Fish and Wildlife Service, Washington, DC.

38. Merchant ME, Shukla SS, Akers HA. 1991. Lead concentrations in wing bones of the mottled duck. Environ Toxicol Chem 10: 1503-1507.

39. Kendall RJ, Scanlon PF. 1981. Effects of chronic lead ingestion on reproductive characteristics of ringed turtle doves Streptopelia risoria and on tissue lead concentrations of adults and their progeny. Environ Pollut A 26:203-213.

40. Fisher FM, Hall SL. 1986. Heavy metal concentrations of duck tissues in relation to ingestion of spent shot. In Feierabend JS, Russell $\mathrm{AB}$, eds, $\mathrm{Pb}$ Poisoning in Wild Waterfowl-A Workshop. National Wildlife Federation, Washington, DC, USA, pp 37-42. 